Authors' contribution/

Wkład autorów:

A. Zaplanowanie badań/

Study design

B. Zebranie danych/

Data collection

C. Analiza statystyczna/

Statistical analysis

D. Interpretacja danych/

Data interpretation

E. Przygotowanie tekstu/

Manuscript preparation

F. Opracowanie

piśmiennictwa/

Literature search

G. Pozyskanie funduszy/

Funds collection
ISSN 2083-3725

\section{DEVELOPMENT OF THE TOURIST FUNCTION WITHIN AREAS OF LOWER SILESIAN LANDSCAPE PARKS}

\section{ROZWÓJ FUNKCJI TURYSTYCZNEJ OBSZARÓW DOLNOŚLĄSKICH PARKÓW KRAJOBRAZOWYCH}

\author{
Jarosław Uglis ${ }^{(A, B, C, D, E, F)}$, Anna Jęczmyk $k^{(A, B, E, F)}$
}

Poznań University of Life Sciences, Department of Rural Tourism

Uniwersytet Przyrodniczy w Poznaniu, Katedra Turystyki Wiejskiej

Uglis J., Jęczmyk A. (2017), Development of the tourist function within areas of lower silesian landscape parks/ Rozwój funkcji turystycznej obszarów dolnoślq̨skich parków krajobrazowych. Economic and Regional Studies, Vol. 10, No. 2, pp. 16-27. https://doi.org/10.2478/ers-2017-0012

\section{ORIGINAL ARTICLE}

JEL code: Q26, C19, Z32

Submitted:

August 2016

Accepted:

April 2017

Tables: 2

Figures: 2

References: 27

\section{Summary}

Subject and purpose of work: The aim of the study was to present the development of the tourist function in the areas of Lower Silesian landscape parks. The subject of the study were the communes associated with Lower Silesian landscape parks.

Materials and methods: The study covered 59 communes of the Lower Silesia Voiovodeship where 12 landscape parks are located. In this research six indicators of the level of tourism development were listed - three in the field of conditions of tourism development and three in the field of tourist traffic.

Results: A significant dependency between the surface area of a landscape park and the state of tourismoriented land development was established. It turned out that among the 59 surveyed communes in 14 of them there are no tourist accommodation facilities.

Conclusions: Based on the conducted surveys, it was found that the highest level of tourist function development occurs in the communes associated with the following landscape parks: Śnieżnik, the Sudety Wałbrzyskie, the Owl Mountains, Książ and Bóbr Valley Landscape Park.

Keywords: tourist function, landscape parks, Lower Silesia

\section{Streszczenie}

Przedmiot i cel pracy: Celem pracy było przedstawienie rozwoju funkcji turystycznej obszarów dolnośląskich parków krajobrazowych. Przedmiotem badań były gminy związane z dolnośląskimi parkami krajobrazowymi.

Materiały i metody: Badaniami objęto 59 gmin województwa dolnośląskiego na terenie których zlokalizowanych było 12 parków krajobrazowych. W badaniu wyznaczono sześć wskaźników opisujących poziom rozwoju funkcji turystycznej - po trzy z zakresu stanu zagospodarowania turystycznego i ruchu turystycznego.

Wyniki: Ustalono istotną zależność między powierzchnią parku krajobrazowego a stanem zagospodarowania turystycznego. Okazało się, że wśród $59 \mathrm{z}$ badanych gmin na terenie $14 \mathrm{z}$ nich nie funkcjonuje ani jeden turystyczny obiekt noclegowy.

Wnioski: Na podstawie przeprowadzonych badań stwierdzono, że najwyższy poziom rozwoju funkcji turystycznej występuje w gminach związanych z następującymi parkami krajobrazowymi: Śnieżnickim, Sudetów Wałbrzyskich, Gór Sowich, Księżańskim i Doliny Bobru.

Słowa kluczowe: funkcja turystyczna, parki krajobrazowe, Dolny Śląsk

Address for correspondence/ Adres korespondencyjny: dr inż. Jarosław Uglis, dr Anna Jęczmyk, Uniwersytet Przyrodniczy w Poznaniu, Katedra Turystyki Wiejskiej, ul. Witosa 45, 61-693 Poznań, Polska; tel.+48 6184662 18; e-mail: uglis@up.poznan.pl, ajeczmyk@up.poznan.pl

Journal indexed in/ Czasopismo indeksowane w: AgEcon Search, AGRO, BazEkon, Index Copernicus Journal Master List, ICV 2015: 81,26; Polish Ministry of Science and Higher Education 2016: 9 points / AgEcon Search, AGRO, BazEkon, Index Copernicus Journal Master List ICV 2015: 81,26; Ministerstwie Nauki i Szkolnictwa Wyższego 2016: 9 punktów. Copyright: (C) 2017 Pope John Paul II State School of Higher Education in Biała Podlaska, Jarosław Uglis, Anna Jęczmyk. All articles are distributed under the terms of the Creative Commons Attribution-NonCommercial-ShareAlike 4.0 International (CC BY-NC-SA 4.0) License (http://creativecommons.org/licenses/by-nc-sa/4.0/), allowing third parties to copy and redistribute the material in any medium or format and to remix, transform, and build upon the material, provided the original work is properly cited and states its license. 


\section{Introduction}

Tourism is one of the most important problems for contemporary environmental protection, yet it is difficult to imagine that protected areas (except for unusual objects) can function without tourists visiting them. Therefore, it is very important to establish principles for organising this activity in protected areas (Radziejowski 2011).

Tourism has a significant impact on the tourist reception area, and in many cases, tourist activity is considered to be one of the directions of local development (Kowalska et al. 2015). The entities that currently manage this form of activity have increased awareness of the benefits of its development, which also contributes to the commencement of measures leading to its flourishing in the areas designated by them (Hendel 2016). So, the essence of economic policy is to create a system of tourism supply. In this regard, tourist organizations should take action within the spatial or economic planning, vocational training and tourism marketing (Kachniewska 2011).

Appropriate approach is particularly important in the case of natural valuable areas, which are often tourist destinations. Areas recommended as priority zones for tourism development are parks whose unique natural and cultural values, combined with a mild protection regime, promote the development of the tourist function (Graja-Zwolińska, Spychała 2014, Uglis, Jęczmyk 2015).

Currently in Poland there are 122 parks (Environmental Protection 2015), which were established due to the natural, historical, cultural and landscape values in order to preserve and promote these values under sustainable development conditions. These areas have protective, sightseeing, tourist, recreational, socioeducational and economic functions. Poland's first landscape park was formally established in 1976 (Suwałki Landscape Park), but the idea dates back to the 1960s. (Radziejowski 2011).

Within the areas bordering the park buffer zones may be designated. In the area of the park one can run a business, but with certain limitations that arise from attention to preserving the natural environment (https://www.mos.gov.pl/ srodowisko/przyroda/formy-ochrony-przyrody/ parki-krajobrazowe/ downloaded on 10/07/2016).

Natural resources are considered to be a form of capital, because they are the source of the inflow of money to a particular area (Łazarek 2004) and in many cases, determine local development (Radziejowski 2006). However, in popular opinion the functioning of environmentally valuable areas is thought to be one of the causes of the of the local community impoverishment. It also leads to limitations of the local government prerogatives, which complicates the decision-making processes. The local community and local authorities are also forced to implement still new, costly protective solutions (Hibszer 2012).

Among the areas where the tourist function develops dynamically, the ones being under legal

\section{Wstęp}

Turystyka stanowi jeden z najważniejszych problemów dla współczesnej ochrony przyrody, ale trudno sobie wyobrazić, aby obszary chronione (poza wyjątkowymi obiektami) mogły funkcjonować bez odwiedzających je turystów. Dlatego też bardzo ważne jest ustalenie zasad organizacji tej aktywności na obszarach chronionych (Radziejowski 2011).

Turystyka ma istotny wpływ na obszar recepcji turystycznej, a w wielu przypadkach działalność turystyczna uznawana jest za jeden z kierunków rozwoju lokalnego (Kowalska i in. 2015). Obecnie podmioty zarządzające tą formą aktywności mają wzrastającą świadomość o korzyściach wynikających z jej rozwoju, co też przyczynia się do rozpoczęcia działań prowadzących do jej rozkwitu na wyznaczonych przez nich obszarach (Hendel 2016). Toteż istotą polityki gospodarczej jest kształtowanie systemu podaży turystycznej. W tym zakresie organizacje turystyczne powinny podejmować działania w obrębie planowania przestrzennego, planowania ekonomicznego, kształcenia zawodowego i marketingu turystycznego (Kachniewska 2011).

Odpowiednie podejście jest szczególnie istotne w przypadku obszarów przyrodniczo cennych, które często stanowią cel podróży turystów. Obszarami predysponowanymi do rozwoju turystyki są parki krajobrazowe, których niepowtarzalne walory przyrodnicze i kulturowe $\mathrm{w}$ połączeniu $\mathrm{z}$ łagodnym reżimem ochronnym, sprzyjają rozwojowi funkcji turystycznej (Graja-Zwolińska, Spychała 2014, Uglis, Jęczmyk 2015).

Obecnie w Polsce istnieją 122 parki krajobrazowe (Ochrona środowiska 2015), które ustanowiono ze względu na wartości przyrodnicze, historyczne i kulturowe oraz walory krajobrazowe w celu zachowania i popularyzacji tych wartości w warunkach zrównoważonego rozwoju. Obszary te pełnią funkcję ochronną, krajoznawcze, turystyczne, rekreacyjne, edukacyjno-wychowawcze oraz gospodarcze. Pierwszy w Polsce park krajobrazowy formalnie został powołany w roku 1976 (Suwalski Park Krajobrazowy), choć ta idea sięga lat 60. XX wieku (Radziejowski 2011).

Na obszarach graniczących z parkiem może zostać wyznaczona otulina. Na terenach parku można prowadzić działalność gospodarczą, jednak z pewnymi ograniczeniami, które wynikają z troski o zachowanie środowiska przyrodniczego (https://www.mos.gov. pl/srodowisko/przyroda/formy-ochrony-przyrody/ parki-krajobrazowe/ data pobrania 10.07.2016).

Walorom przyrodniczym przypisuje się charakter kapitału, gdyż są one źródłem napływu pieniądza do konkretnego obszaru (Łazarek 2004) i w wielu przypadkach warunkują lokalny rozwój (Radziejowski 2006). Jednak w potocznej opinii funkcjonowanie obszarów przyrodniczo cennych uważa się za jedną z przyczyn zubożenia lokalnej społeczności. Dochodzi również do zmniejszenia zakresu kompetencji lokalnych władz samorządowych, co komplikuje procesy decyzyjne. Społeczność lokalna i władze samorządowe zmuszone są także do wprowadzania ciągle nowych, kosztowniejszych rozwiązań ochronnych (Hibszer 2012). 
protection are gaining more importance, especially protected areas of lower rank. High intensity of tourist traffic and excessive exploration of national parks, lead to their degradation and therefore so much emphasis is placed on the development of tourist and recreational offer of landscape parks and protected landscape areas (Sokołowski et al. 2011 Kobyłka, Sawicki 2016).

Without a doubt, tourism is a phenomenon whose direct measurement is very difficult. Attempts to estimate the size of tourism demand were already made half a century ago, when the use of symptomatic measurements was initiated (Szromek 2013a). These measurements allowed for depicting the development level of tourist functions in given areas because they based on the measurement of tourist traffic and development. However, they were ambiguous (Szromek 2013b). The need to relate particular variables associated with tourism to the variables being reference measures (surface area or the number of residents of the area) has prompted researchers to develop tourist function indicators (Szromek 2013) which determines the importance of this activity in the economic structure of a spatial unit.

The available literature shows many aspects of the issue of tourist function. Geographical (Zajadacz 2014, Derek 2008) and economic approaches are distinguished (Gałecki 2004, Dziedzic 2003). It should be noted that, it was initially identified mainly with the first approach (Piotrowski 2015, p. 58). As Matczak noted (1989) it is "socio-economic activity of the location or area, which is intended to provide services to tourists" (Derek 2007, p. 29). In economic terms the tourist function is understood as "every socio-economic activity within a location or region, aimed at tourist services, from which its ability to meet specific needs of tourism arises" (Kurek 2007).

At the turn of the XX and XXI centuries the need for more objective indicators of tourist function was noted. Indicators might synthetically define the picture of the ongoing changes, while taking into account aspects previously diagnosed by traditional indicators (Szromek 2013b). This function may occur within the functional structure of the location or area as a dominant economic function, equivalent or one of many component functions, as well as a supplementary or additional function (Jackowski 1981, Spychała 2010). It is of special importance in terms of environmentally valuable areas, including landscape parks, because it should be implemented as a collaboration between the administration of the parks and the local population together with the local governments representing it, which will ensure proper development of tourism. The tourist function should not constitute the leading direction in the development of protected areas; it should only be a complementary activity, which cooperates with the primary activity, which is the environmental protection and and prevention of anthropopression

The aim of the study is to assess the diversification of tourist function development within the areas of Lower Silesia landscape parks.
Wśród obszarów o rozwijającej sie funkcji turystycznej coraz większą rolę zyskują tereny objęte ochroną prawną, przede wszystkim obszary chronione niższej rangi. Duże natężenie ruchu turystycznego i nadmierna eksploracja parków narodowych, prowadzą do ich degradacji, stąd duży nacisk kładziony jest na rozbudowę oferty turystyczno-rekreacyjnej parków krajobrazowych i obszarów chronionego krajobrazu (Sokołowski i in. 2011, Kobyłka, Sawicki 2016).

Bez wątpienia turystyka jest zjawiskiem, którego bezpośredni pomiar jest bardzo trudny. Próby szacowania wielkości popytu turystycznego były podejmowane już pół wieku temu, kiedy to zainicjowano użycie miar o charakterze symptomatycznym (Szromek 2013a). Mierniki te umożliwiły zobrazowanie poziomu rozwoju funkcji turystycznej obszarów, gdyż opierały się na pomiarze ruchu i zagospodarowania turystycznego. Miały one jednak charakter niejednoznaczny (Szromek 2013b). Potrzeba odniesienia poszczególnych zmiennych związanych z turystyką do zmiennych będących miarami odniesienia, (powierzchnia obszaru lub liczba mieszkańców tego obszaru) skłoniła badaczy do opracowania wskaźników funkcji turystycznej (Szromek 2013a), która określa znaczenie tej aktywności w strukturze gospodarczej jednostki przestrzennej.

W literaturze pojawia się wiele aspektów problemu funkcji turystycznej. Wyróżnia się ujęcie geograficzne (Zajadacz 2014, Derek 2008) i ekonomiczne (Gałecki 2004, Dziedzic 2003). Warto podkreślić, że pierwotnie utożsamiano ją głównie z tym pierwszym podejściem (Piotrowski 2015, s. 58). Jak zauważa Matczak (1989) jest to „działalność społeczno-ekonomiczna miejscowości lub obszaru, która jest skierowana na obsługę turystów” (za Derek 2007, s. 29). W ujęciu ekonomicznym funkcję turystyczną rozumie się, jako „wszelką działalność społeczno-ekonomiczną w miejscowości lub regionie, skierowaną na obsługę turystów, z której wynika jej (jego) zdolność do zaspokojenia określonych potrzeb turystycznych" (Kurek 2007).

Na przełomie XX i XXI wieku zauważono potrzebę opracowania bardziej obiektywnych wskaźników funkcji turystycznej, które syntetycznie ujmowałyby obraz zachodzących zmian, uwzględniając zarazem aspekty dotąd diagnozowane przez tradycyjne wskaźniki (Szromek 2013b). W strukturze funkcjonalnej miejscowości lub obszaru omawiana funkcja może występować jako dominująca funkcja gospodarcza lub równorzędna, albo jedna $\mathrm{z}$ wielu funkcji składowych, jak też uzupełniająca bądź dodatkowa (Jackowski 1981, Spychała 2010). Szczególnego znaczenia nabiera ona $\mathrm{w}$ aspekcie obszarów przyrodniczo cennych, w tym parków krajobrazowych, albowiem powinna być prowadzona jako współpraca pomiędzy administracją parków a ludnością miejscową i reprezentującymi ją samorządami, co zapewni właściwy rozwój turystyki. Funkcja turystyczna nie powinna stanowić wiodącego kierunku w rozwoju obszarów chronionych, a jedynie być aktywnością komplementarną, która współdziała z działalnością nadrzędną, jaką jest ochrona środowiska i zapobieganie antropopresji.

Celem opracowania jest ocena zróżnicowania rozwoju funkcji turystycznej obszarów dolnośląskich parków krajobrazowych. 


\section{Material and methods}

Indicator methods were used during the research in order to show the spatial variation of tourist function development within the areas of Lower Silesian landscape parks. In order to indicate particular aspects of the development of this function the research required the use of multiple indicators, which should fully characterize tourist functions of the surveyed units. The study assumed that they should reflect both the level of tourism development and at the same time the scale of the tourist traffic intensity.

The analysis of the development of tourist function (in spatial approach) was conducted on the basis of the data from the Local Data Bank of the Central Statistical Office for 2014 and the study involved 59 communes in whose area Lower Silesia landscape parks are located. The database was created with variables such as:

- the number of tourist accommodation facilities ${ }^{1}$,

- accommodation capacity,

- the number of users: residents and foreign tourists,

- number of nights spent by residents and foreign tourists,

- area of the commune,

- population number (residents),

- landscape park area.

The collected material was used to determine six indicators that characterise the spatial picture of the level of tourist function development in the studied area. The next step was to analyse the statistical relationships between the area of landscape parks and the ability of the studied units to perform the tourist function based on Pearson's linear correlation coefficient. In this work the area share of landscape parks in the total area of a given commune was adopted as an explanatory variable, while the listed indicators were adopted as explained variables. For additional support a cluster analysis using Ward's and k-means method was used. The necessary statistical analyses were performed with the STATISTICA 12 program.

\section{Characteristics of the studied area}

Lower Silesia is a region rich in valuable natural areas, which are attractive tourist destination due to their natural beauty and numerous attractions (Mastalska-Cetera, Warczewska 2015). Many forms of nature protection are in place in the Lower Silesian Voivodeship, including 12 landscape parks, one of which is of a cross-border character. In general, landscape parks occupy here a total of over 206.3 thousand ha (over 284.5 thousand ha together with the buffer zone), which in relation to the total area of the province is $10.3 \%$. With considerations for the specific character of a given park, protection

\footnotetext{
${ }^{1}$ Starting with 2012 , the data on tourist accommodation facilities (formerly known as "collective tourist accommodation establishments") also includes the data on guest rooms and lodgings with 10 or more bed places.
}

\section{Materiał i metody}

W postępowaniu badawczym zastosowano metody wskaźnikowe w celu przedstawienia przestrzennego zróżnicowania rozwoju funkcji turystycznej obszarów dolnośląskich parków krajobrazowych. Wskazanie poszczególnych aspektów rozwoju tej funkcji wymagało zastosowania wielorakich wskaźników, które powinny wyczerpująco charakteryzować funkcje turystyczne badanych jednostek. W pracy przyjęto, że powinny one odzwierciedlać zarówno poziom zagospodarowania turystycznego oraz jednocześnie skalę intensywności ruchu turystycznego.

Analizy rozwoju funkcji turystycznej (w ujęciu przestrzennym) dokonano na podstawie danych Banku Danych Lokalnych GUS za 2014 r., a badaniem objęto 59 gmin na terenie których zlokalizowane są dolnośląskie parki krajobrazowe. Bazę danych utworzono z takich zmiennych, jak:

- liczba turystycznych obiektów noclegowych ${ }^{1}$,

- liczba miejsc noclegowych,

- liczba korzystających rezydentów i turystów zagranicznych,

- liczba udzielonych noclegów rezydentom i turystom zagranicznym,

- powierzchnia gminy,

- liczba ludności (rezydentów),

- powierzchnia parku krajobrazowego.

Zgromadzony materiał faktualny posłużył do wyznaczenia sześciu wskaźników opisujących przestrzenny obraz poziomu rozwoju funkcji turystycznej badanego obszaru. Następnie dokonano analizy związków statystycznych pomiędzy powierzchną obszarów parków krajobrazowych a zdolnością badanych jednostek do pełnienia funkcji turystycznej na podstawie współczynnika korelacji liniowej Pearsona. W pracy przyjęto jako zmienną objaśniającą udział w powierzchni parków krajobrazowych w ogólnej powierzchni gminy, natomiast jako zmienne objaśniane kolejno wyliczone wskaźniki. Dodatkowo pomocniczo zastosowano analizę skupień metodą Warda i k-średnich. Niezbędne analizy statystyczne przeprowadzono w programie STATISTICA 12.

\section{Charakterystyka badanego obszaru}

Dolny Śląsk jest regionem obfitującym w obszary przyrodniczo cenne, które stanowią atrakcyjne miejsce podróży wielu turystów ze względu na walory przyrodnicze i liczne atrakcje (Mastalska-Cetera, Warczewska 2015). W województwie dolnośląskim wyznaczonych jest wiele form sytemu ochrony przyrody, w tym 12 parków krajobrazowych, z których jeden ma transgraniczny charakter. Ogółem parki krajobrazowe zajmują tu łącznie ponad 206,3 tys. ha (łącznie z otuliną ponad 284,5 tys. ha), co w stosunku do ogólnej powierzchni województwa stanowi 10,3\%. Biorąc pod uwagę specyfikę danego parku ochroną objęte są jego

\footnotetext{
Począwszy do 2012 r. dane dotyczące turystycznych obiektów noclegowych (wcześniejsza nazwa "turystyczne obiekty zbiorowego zakwaterowania") obejmują "również dane z pokoi gościnnych i kwater agroturystycznych posiadających 10 i więcej miejsc noclegowych.
} 
is applied to its unique qualities (natural, historical and cultural). Forest and agricultural landscape type is predominant in the studied parks (Table 1). unikatowe walory (przyrodnicze, historyczne i kulturowe). W badanych parkach zdecydowanie dominuje leśny i rolniczy typ krajobrazu (tabela 1 ).

Table 1. Landscape Parks in the Lower Silesian Voivodeship

Tabela 1. Parki krajobrazowe na terenie województwa dolnośląskiego

\begin{tabular}{|c|c|c|c|c|c|}
\hline $\begin{array}{l}\text { No./ } \\
\text { Lp. }\end{array}$ & $\begin{array}{l}\text { Name/ } \\
\text { Nazwa }\end{array}$ & $\begin{array}{c}\text { Type of } \\
\text { landscape/ } \\
\text { Typ } \\
\text { krajobrazu }\end{array}$ & $\begin{array}{c}\text { Year } \\
\text { of creation/ } \\
\text { Rokutwo- } \\
\text { rzenia }\end{array}$ & $\begin{array}{c}\text { Area ha } \\
\text { (buffer zone)/ } \\
\text { Powierzchnia- } \\
\text { ha(otulina) }\end{array}$ & $\begin{array}{l}\text { Administrative location } \\
\text { (commune)/ } \\
\text { Położenie administracyj- } \\
\text { ne(gmina) }\end{array}$ \\
\hline 1 & Chełmy & $\mathrm{L} / \mathrm{R}$ & 1992 & $\begin{array}{c}15990.76 \\
(12470.83)\end{array}$ & $\begin{array}{l}\text { Paszowice, Męcinka, Złotoryja, } \\
\text { Krotoszyce, Jawor }\end{array}$ \\
\hline 2 & $\begin{array}{l}\text { Barycz River Valley/ } \\
\text { Dolina Baryczy }\end{array}$ & W/L & 1996 & $70040^{*}$ & $\begin{array}{c}\text { Cieszków, Krośnice, Milicz, } \\
\text { Prusice, Trzebnica, Twardogóra, } \\
\text { Żmigród }\end{array}$ \\
\hline 3 & $\begin{array}{l}\text { Bóbr River Valley/ } \\
\text { Dolina Bobru }\end{array}$ & $\mathrm{R} / \mathrm{W}$ & 1989 & $\begin{array}{c}10943 \\
(12552)\end{array}$ & $\begin{array}{c}\text { Jeżów Sudecki, Stara Kamienica, } \\
\text { Lubomierz, Lwówek Śląski, Wleń, } \\
\text { Jelenia Góra }\end{array}$ \\
\hline 4 & $\begin{array}{c}\text { Bystrzyca River Valley/ } \\
\text { Dolina Bystrzycy }\end{array}$ & $\mathrm{L} / \mathrm{W}$ & 1998 & 8570 & $\begin{array}{c}\text { Wrocław, Kąty Wrocławskie, } \\
\text { Mietków, Sobótka, Miękinia }\end{array}$ \\
\hline 5 & $\begin{array}{c}\text { Jezierzyca River Valley/ } \\
\text { Dolina Jezierzycy }\end{array}$ & $\mathrm{L} / \mathrm{W}$ & 1994 & 7953 & Wołów, Wińsko \\
\hline 6 & $\begin{array}{l}\text { Owl Mountains/ } \\
\text { Gór Sowich }\end{array}$ & $\mathrm{R}, \mathrm{L}$ & 1991 & 8140 & $\begin{array}{c}\text { Pieszyce, Bielawa, Dzierżoniów, } \\
\text { Głuszyca, Walim, Stoszowice, } \\
\text { Nowa Ruda } \\
\end{array}$ \\
\hline 7 & Książański & $\mathrm{L}, \mathrm{K}, \mathrm{W}$ & 1981 & $\begin{array}{l}3155.40 \\
(5933)\end{array}$ & $\begin{array}{c}\text { Wałbrzych, Stare Bogaczawice, } \\
\text { Dobromierz, Świebodzice, } \\
\text { Świdnica }\end{array}$ \\
\hline 8 & Przemkowski & W/L & 1997 & $\begin{array}{c}22340 \\
(15467)\end{array}$ & $\begin{array}{l}\text { Przemków, Gaworzyce, } \\
\text { Radwanice, Gromadka }\end{array}$ \\
\hline 9 & Rudawski & $\mathrm{R} / \mathrm{L}$ & 1989 & $\begin{array}{l}15705 \\
(6600)\end{array}$ & $\begin{array}{l}\text { Bolków, Janowice Wielkie, } \\
\text { Kamienna Góra, Kowary, } \\
\text { Marciszów, Mysłakowice }\end{array}$ \\
\hline 10 & $\begin{array}{l}\text { Sudety Wałbrzyskie Mountains/ } \\
\text { Sudetów Wałbrzyskich }\end{array}$ & $\mathrm{R} / \mathrm{L}$ & 1998 & $\begin{array}{c}6493 \\
(2894)\end{array}$ & $\begin{array}{c}\text { Czarny Bór, Mieroszów, Głuszyca, } \\
\text { Wałbrzych, Boguszów Gorce, } \\
\text { Jedlina-Zdrój }\end{array}$ \\
\hline 11 & Ślężański & $\mathrm{R} / \mathrm{L}$ & 1988 & $\begin{array}{c}8190 \\
(7450)\end{array}$ & $\begin{array}{c}\text { Jordanów Śląski, Dzierżoniów, } \\
\text { Łagiewniki, Marcinowice, Sobótka }\end{array}$ \\
\hline 12 & Śnieżnicki & $\mathrm{R}, \mathrm{L}$ & 1981 & $\begin{array}{c}28800 \\
(14900)\end{array}$ & $\begin{array}{l}\text { Złoty Stok, Bystrzyca Kłodzka, } \\
\text { Kłodzko, Lądek Zdrój, } \\
\text { Międzylesie, Stronie Śląskie }\end{array}$ \\
\hline 13 & $\begin{array}{c}\text { Total/ } \\
\text { Łącznie }\end{array}$ & & & $\begin{array}{l}206320.16 \\
(78266.83)\end{array}$ & 59 \\
\hline
\end{tabular}

*in the Lower Silesian Voivodeship, the total area of landscape parks is 87040 ha type of landscape: R - agricultural, L - forest, W - water, K - cultural

*na terenie woj. dolnośląskiego, całkowita powierzchnia parku 87040 ha typ krajobrazu: R - rolniczy, L - leśny, W - wodny, K - kulturowy

Source: the author's own work based on: http://dzpk.pl/pl/parki-krajobrazowe.html [accessed on 08/07/2016]. Źródło opracowanie własne na podstawie: http://dzpk.pl/pl/parki-krajobrazowe.html [dostęp dn. 8.07.2016].

In the Lower Silesian Voivodeship the following are among the oldest landscape parks: Książ and Śnieżnik, created in 1981. In turn, the youngest landscape parks are the following: Bystrzyca River Valley and Sudety Wałbrzyskie Mountains. In terms of area, the largest landscape park is the Barycz River Valley whereas the smallest park is Książ Landscape Park. Within the discussed area its specific, and at the same time unique, qualities of were placed under protection with the aim of conservation and popularisation.
W województwie dolnośląskim do najstarszych parków krajobrazowych zaliczane są: Książański i Śnieżnicki, które utworzono w roku 1981. Z kolei do najmłodszych należą parki krajobrazowe: Dolina Bystrzycy i Sudetów Wałbrzyskich. Największym obszarowo parkiem jest Dolina Baryczy, najmniejszy zaś park Książański. Na omawianych obszarach ochroną objęto specyficzne i zarazem unikatowe jego walory w celu ich zachowania oraz popularyzacji. 


\section{Research outcome}

The ability of a given area to develop the tourist function depends on many factors, in particular on local resources. The natural and cultural values represent a unique potential that constitutes an impulse for developing the required tourist, technical and social infrastructure. Undoubtedly, tourism-oriented land development affects the intensity and spatial distribution of tourist traffic and its structure and forms.

The primary way to depict the development level of tourist facilities in the studied parks is to present it through the state of accommodation facilities (number of tourist accommodation facilities and its capacity), which gives an indication of the importance of tourism in the economy of a given area. Examining the state of accommodation facilities development in the communes revealed that within the administrative borders of fourteen units (23.7\%) analysed in 2014 there were no tourist accommodation facilities offering 10 or more bed places. Given the availability of the necessary data provided by the Local Data Bank of Central Statistical Office (CSO) and the substantive justification, the data used for further calculations referred to 43 communes ${ }^{2}$, as there were no operating tourist accommodation facilities in fourteen studied communes.

The analysis of the capacity of the accommodation facilities in the studied communes revealed 177 tourist accommodation facilities (having 10 or more bed places) of various types, offering a total of 8095 bed places.

Chełmy Landscape Park/ PK Chełmy

Barycz Valley Landscape Park/ PK Dolina Baryczy

Bóbr Valley Landscape Park/ PK Dolina Bobru

Bystrzyca Valley Landscape Park/ PK Dolina Bystrzycy

Jezierzyca Valley Landscape Park/ PK Dolina Jezierzycy

Owl Mountains Landscape Park/ PK Gór Sowich

Książ Landscape Park/ Książański PK

Przemków Landscape Park/ Przemkowski PK

Rudawy Landscape Park/ Rudawski PK

Sudety Wałbrzyskie Landscape Park/ PK Sudetów Wałbrzyskich

Ślęża Landscape Park/ Ślężański PK

Śnieżnik Landscape Park/ Śnieżnicki PK

\section{Wyniki badań}

Możliwość danego obszaru do rozwoju funkcji turystycznej uzależniona jest od wielu czynników, a w szczególności od lokalnych zasobów. Walory przyrodnicze i kulturowe stanowią niepowtarzalny potencjał, który stanowi asumpt do rozwoju potrzebnej infrastruktury turystycznej, technicznej i społecznej. Bez wątpienia zagospodarowanie turystyczne wpływa na intensywność i rozkład przestrzenny ruchu turystycznego oraz na jego strukturę i formy.

Podstawowym sposobem przedstawienia poziomu zagospodarowania turystycznego badanych parków jest pokazanie go poprzez stan bazy noclegowej (liczba turystycznych obiektów noclegowych i liczba miejsc noclegowych), który świadczy o znaczeniu turystyki dla gospodarki danego obszaru. Badając stan rozwoju bazy noclegowej w gminach okazało się, że $\mathrm{w}$ granicach administracyjnych czternastu $\mathrm{z}$ analizowanych jednostek $(23,7 \%)$ w 2014 roku nie funkcjonował ani jeden turystyczny obiekt noclegowy posiadający 10 lub więcej miejsc noclegowych. Biorąc pod uwagę dostępność niezbędnych danych udostępnionych w Banku Danych Lokalnych GUS oraz przesłanki merytoryczne, do dalszych obliczeń wykorzystano dane dla $43 \mathrm{gmin}^{2}$, albowiem na terenie czternastu $\mathrm{z}$ badanych gmin nie funkcjonował ani jeden turystyczny obiekt noclegowy.

Analizując rozmiary bazy noclegowej w badanych gminach stwierdzono 177 turystycznych obiektów noclegowych (posiadający 10 lub więcej miejsc noclegowych) różnego typu, oferujących łącznie 8095 miejsc noclegowych.

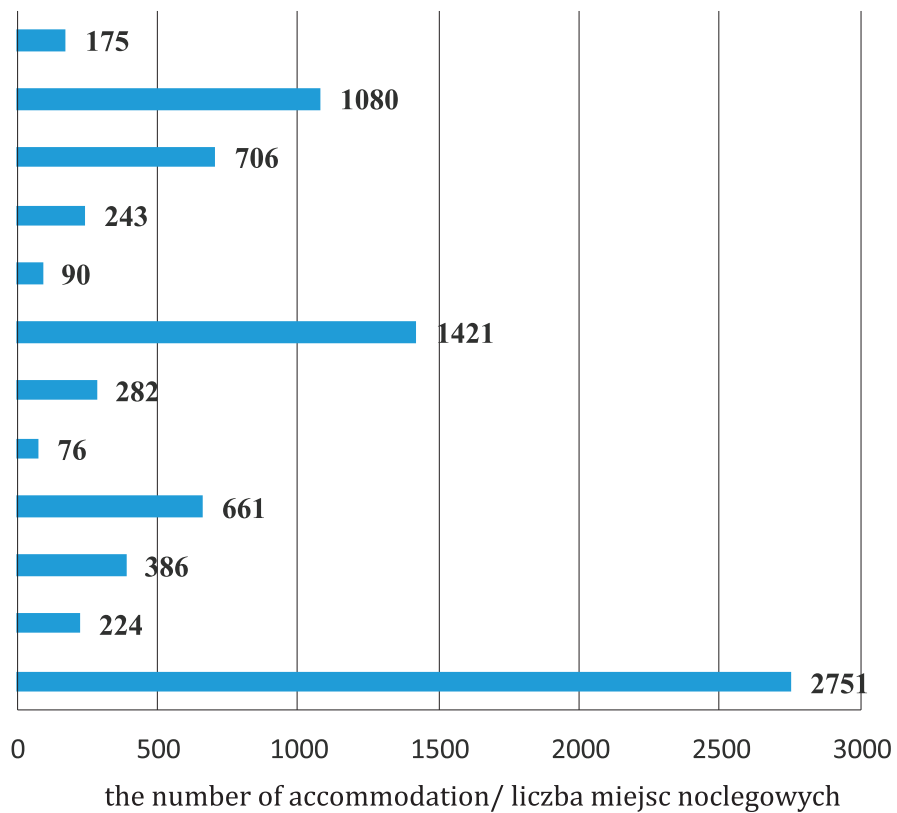

the number of accommodation/ liczba miejsc noclegowych

Figure 1. The capacity of accommodation facilities in the Lower Silesian landscape parks and their surroundings Rysunek 1. Wielkość bazy noclegowej w dolnośląskich parkach krajobrazowych oraz ich otoczeniu

Source: authors' own study based on the Local Data Bank (BDL), and GUS data.

Źródło: opracowanie własne na podstawie danych BDL GUS.

\footnotetext{
Communes of Wrocław and Jelenia Góra were excluded from the study sample.
}

\footnotetext{
Z badanej próby wyłączono gminę miejską Wrocław i Jelenia Góra.
} 
The largest accommodation capacity was found in communes related with the Śnieżnik Landscape Park and Owl Mountains Landscape Park (Figure 1). Together, they accounted for more than half (51.5\%) of bed places in the studied areas. On the other hand, in Przemków Landscape Park and Jezierzyca River Valley the lowest number of bed places was recorded.

The assessment of the degree of accommodation basis development is also made by the number of tourists using accommodation services and the length of their stay expressed as a number of overnight stays. According to the data, in 2014 accommodation services were used by more than 212.9 thousand of tourists, who were provided a total of over 576.5 thousand overnight stays. Thus, the average length of stay was 2.7 overnight stays.

In addition to numerical characteristics, intensity indicators related to the population size and area were also used for description. For this purpose, indicators of the density of accommodation facilities, i.e. Barteje's, Schneider's, Charvat's and Defert's indicators were applied (Table 2).

Significant spatial variations in both the development of tourist facilities and tourist traffic have been demonstrated on the basis of the conducted analyses. The largest number of tourist accommodation facilities per $100 \mathrm{~km}^{2}$ and the density of accommodation (per $1 \mathrm{~km}^{2}$ ) was recorded in the commune of Jedlina-Zdrój. Baretje's indicator, on the other hand, is a measurement showing the relation of the number of bed places to the number of residents in a particular area. The analysis of this indicator indicated that, on average, there were 2 bed places per one hundred residents. The units with the largest number of bed places were the following communes: Stronie Śląskie, Lądek Zdrój, Walim, Jedlina-Zdrój and Stara Kamienica, and the communes with the least-developed Baretje's tourist function were Miękinia, Twardogóra, Świebodzice, Czarny Bór and Dobromierz (Table 2).

The analysis of correlation confirmed the existence of a statistically significant interdependence between the area share of the landscape park and the calculated indicators of the development level:

- the number of tourist accommodation facilities per $100 \mathrm{~km}^{2}$ - Pearson's correlation coefficient $\left(r_{x y}\right): 0.312(p=0.042)$,

- Baretje's tourist function indicator - Pearson's linear correlation coefficient ( $r x y$ ): 0.315 ( $p=$ 0.039 ).

The calculated correlation coefficient value indicates a positive correlation between the studied features characterised by moderate strength of relation. In the case of the density of accommodation indicator, the calculated value of the correlation indicator $\left(\mathrm{r}_{\mathrm{xy}}=0.253\right.$ was statistically insignificant at $\alpha=0.05$.

In order to make a comprehensive assessment of the capability of functioning as a tourist area, the data on tourist traffic was analysed. The calculated values of tourism intensity are shown in Table 2. The spatial distribution of the indicators
Najwięcej miejsc noclegowych stwierdzono w gminach związanych z Śnieżnickim Parkiem Krajobrazowym i Parkiem Krajobrazowym Gór Sowich (rysunek 1). Razem stanowiły one ponad połowę $(51,5 \%)$ miejsc noclegowych badanych obszarów. Z kolei w parku krajobrazowym Przemkowskim i Dolina Jezierzycy zanotowano najmniejszą liczbę miejsc noclegowych.

Oceny stopnia rozwoju bazy noclegowej dokonuje się również poprzez liczbę korzystających turystów z usług noclegowych oraz długość ich pobytu wyrażoną liczbą udzielonych noclegów. Według danych w 2014 r. z usług bazy noclegowej skorzystało ponad 212,9 tys. turystów, którym łącznie udzielono ponad 576,5 tys. noclegów. Zatem przeciętna długość pobytu wyniosła 2,7 noclegu.

Oprócz charakterystyk liczbowych do opisu wykorzystano również wskaźniki natężenia odnoszące się do liczby mieszkańców i powierzchni. W tym celu zastosowano wskaźniki gęstości bazy noclegowej, Barteje'a, Schneidera, Charvata i Deferta (tabela 2).

Na podstawie przeprowadzonych analiz wykazano znaczące zróżnicowanie przestrzenne zarówno stanu zagospodarowania turystycznego, jak i ruchu turystycznego. Największą liczbę turystycznych obiektów noclegowych na $100 \mathrm{~km}^{2}$ i gęstości bazy noclegowej (na $1 \mathrm{~km}^{2}$ ) odnotowano w gminie Jedlina-Zdrój. Z kolei miernikiem ukazującym relację liczby miejsc noclegowych do liczby rezydentów obszaru jest wskaźnik Baretje’a. W ramach analizy powyższego wskaźnika stwierdzono, że średnio na stu mieszkańców przypadały 2 miejsca noclegowe. Jednostkami o największej liczbie miejsc noclegowych okazały się gminy: Stronie Śląskie, Lądek-Zdrój, Walim, Jedlina-Zdrój i Stara Kamienica, natomiast gminami o najsłabiej rozwiniętej funkcji turystycznej Baretje’a były: Miękinia, Twardogóra, Świebodzice, Czarny Bór i Dobromierz (tabela 2).

Z przeprowadzonej analizy korelacji wynika statystycznie istotna współzależność miedzy udziałem powierzchni parku krajobrazowego a obliczonymi wskaźnikami poziomu zagospodarowania:

- liczba turystycznych obiektów noclegowych na $100 \mathrm{~km}^{2}$ - współczynnik korelacji liniowej Pearsona $\left(r_{x y}\right): 0,312(p=0,042)$,

- wskaźnik funkcji turystycznej Baretje’a - współczynnik korelacji liniowej Pearsona (rxy): 0,315 $(\mathrm{p}=0,039)$.

Obliczona wartość współczynnika korelacji wskazuje na dodatnią zależność pomiędzy badanymi cechami o umiarkowanej sile związku. W przypadku wskaźnika gęstości bazy noclegowej obliczona wartość wskaźnika korelacji $\left(\mathrm{r}_{\mathrm{xy}}=0,253\right.$ okazała się nieistotna statystycznie na poziomie $\alpha=0,05$.

W celu dokonania kompleksowej oceny zdolności do pełnienia funkcji turystycznej obszaru poddano analizie dane dotyczące ruchu turystycznego. Obliczone wartości wskaźników intensywności turystycznej zamieszczono w tabeli 2 . Rozkład przestrzenny wartości wskaźników wskazuje na duże ich zróżnicowanie. Na podstawie obliczeń średniej wartości wskaźnika Schneidera wykazano, że na stu mieszkańców przypadało 53 turystów. Z obliczeń 
Table 2. The criteria for the classification of the tourist function

Tabela 2. Kryteria klasyfikacji funkcji turystycznej

\begin{tabular}{|c|c|c|c|c|c|c|}
\hline \multirow[b]{3}{*}{$\begin{array}{c}\text { Description/ } \\
\text { Wyszczególnienie }\end{array}$} & \multicolumn{6}{|c|}{ Indicators/Wskaźniki } \\
\hline & \multicolumn{3}{|c|}{$\begin{array}{l}\text { level of tourist facilities development/ } \\
\text { poziom zagospodarowania turystycznego }\end{array}$} & \multicolumn{3}{|c|}{$\begin{array}{l}\text { intensity of tourist traffic/ } \\
\text { intensywność ruchu turystycznego }\end{array}$} \\
\hline & \begin{tabular}{|c|} 
number of tourist \\
accommodation faci- \\
lities per $100 \mathrm{~km}^{2} /$ \\
liczba turystycznych \\
obiektów noclego- \\
wych na $100 \mathrm{~km}^{2}$ \\
\end{tabular} & $\begin{array}{l}\text { density of ac- } \\
\text { commodation } \\
\text { facilities/ } \\
\text { gęstości bazy } \\
\text { noclegowej }\end{array}$ & $\begin{array}{c}\text { Baretje's } \\
\text { tourist } \\
\text { function/ } \\
\text { funkcji tu- } \\
\text { rystycznej } \\
\text { Baretje'a } \\
\end{array}$ & \begin{tabular}{|} 
according \\
to \\
Schneider/ \\
wedługSch- \\
neidera
\end{tabular} & $\begin{array}{l}\text { according } \\
\text { to } \\
\text { Charvat/ } \\
\text { według- } \\
\text { Charvata }\end{array}$ & $\begin{array}{c}\text { tourist } \\
\text { function } \\
\text { Defert's/ } \\
\text { funkcji } \\
\text { turystycz- } \\
\text { nejDeferta }\end{array}$ \\
\hline Bielawa & 8.3 & 5.69 & 0.7 & 17.6 & 33.1 & 284.9 \\
\hline Bolków & 2.6 & 1.57 & 2.2 & 24.0 & 54.7 & 38.7 \\
\hline Bystrzyca Kłodzka & 4.1 & 2.59 & 4.5 & 140.5 & 446.5 & 256.1 \\
\hline Czarny Bór & 1.5 & 0.20 & 0.3 & 2.3 & 10.2 & 7.5 \\
\hline Dobromierz & 1.2 & 0.17 & 0.3 & 0.3 & 1.0 & 0.6 \\
\hline Janowice Wielkie & 1.8 & 0.35 & 0.5 & 11.2 & 27.3 & 20.8 \\
\hline Jedlina-Zdrój & 35.3 & $\mathbf{1 4 . 5}$ & 4.9 & 92.7 & 622.2 & 1820.9 \\
\hline Jeżów Sudecki & 2.1 & 0.28 & 0.4 & 4.6 & 19.5 & 14.7 \\
\hline Kamienna Góra $^{1}$ & 11.1 & 3.50 & 0.3 & 14.0 & 18.5 & 204.7 \\
\hline Kamienna Góra $^{2}$ & 1.3 & 0.25 & 0.4 & 8.1 & 22.9 & 13.0 \\
\hline Kąty Wrocławskie & 2.3 & 0.68 & 0.5 & 17.2 & 50.4 & 64.4 \\
\hline Kłodzko & 0.8 & 0.48 & 0.7 & 43.1 & 65.9 & 45.4 \\
\hline Kowary & 13.5 & 7.68 & 2.5 & 48.7 & 132.2 & 407.6 \\
\hline Krośnice & 2.2 & 1.07 & 2.3 & 50.2 & 150.1 & 69.1 \\
\hline Lądek-Zdrój & 12.8 & 5.97 & 8.2 & 243.3 & 833.7 & 608.5 \\
\hline Lubomierz & 2.3 & 0.48 & 1.0 & 12.2 & 27.4 & 12.9 \\
\hline Lwówek Śląski & 1.3 & 0.85 & 1.2 & 9.2 & 15.6 & 11.4 \\
\hline Marcinowice & 3.2 & 0.79 & 1.1 & 67.3 & 176.5 & 121.3 \\
\hline Marciszów & 1.2 & 0.17 & 0.3 & 2.0 & 9.3 & 5.3 \\
\hline Mieroszów & 7.9 & 1.67 & 1.8 & 48.9 & 95.8 & 89.3 \\
\hline Międzylesie & 2.6 & 0.97 & 2.5 & 60.8 & 153.1 & 60.2 \\
\hline Miękinia & 0.6 & 0.13 & 0.2 & 0.5 & 4.4 & 3.6 \\
\hline Milicz & 1.1 & 0.78 & 1.4 & 25.4 & 82.9 & 46.4 \\
\hline Nowa Ruda & 5.7 & 3.61 & 4.2 & 38.6 & 105.9 & 90.5 \\
\hline Pieszyce & 4.7 & 1.55 & 1.0 & 9.3 & 21.8 & 32.7 \\
\hline Prusice & 0.6 & 0.38 & 0.6 & 29.4 & 39.2 & 23.2 \\
\hline Przemków & 1.9 & 0.71 & 0.9 & 45.9 & 157.8 & 129.4 \\
\hline Sobótka & 3.7 & 1.83 & 1.9 & 41.0 & 66.9 & 62.9 \\
\hline Stara Kamienica & 1.8 & 2.18 & 4.6 & 203.3 & 686.9 & 328.5 \\
\hline Stare Bogaczowice & 1.1 & 0.25 & 0.5 & 18.4 & 35.0 & 16.9 \\
\hline Stoszowice & 2.7 & 1.38 & 2.8 & 135.8 & 307.3 & 150.9 \\
\hline Stronie Śląskie & 14.4 & 5.23 & 9.9 & 167.7 & 485.4 & 255.6 \\
\hline Świdnica & 1.0 & 0.89 & 1.1 & 47.7 & 162.2 & 132.4 \\
\hline Świebodzice & 6.7 & 2.00 & 0.3 & 12.7 & 48.1 & 372.3 \\
\hline Trzebnica & 2.5 & 1.31 & 1.1 & 48.8 & 73.3 & 86.9 \\
\hline Twardogóra & 0.6 & 0.18 & 0.2 & 8.8 & 27.9 & 21.6 \\
\hline Walim & 16.5 & 5.77 & 8.1 & 217.2 & 464.8 & 333.1 \\
\hline Wałbrzych & 14.1 & 11.25 & 0.8 & 44.2 & 77.1 & 1057.9 \\
\hline Wleń & 5.8 & 1.99 & 3.9 & 40.7 & 126.4 & 64.7 \\
\hline Wołów & 1.2 & 0.27 & 0.4 & 8.7 & 21.8 & 15.1 \\
\hline Złotoryja & 1.4 & 1.21 & 2.5 & 182.1 & 248.2 & 122.1 \\
\hline Złoty Stok & 4.0 & 1.44 & 2.3 & 64.5 & 193.6 & 121.0 \\
\hline Żmigród & 0.3 & 0.68 & 1.3 & 0.9 & 3.2 & 1.6 \\
\hline Average/Średnia & 4.9 & 2.2 & 2.0 & 53.7 & 149.0 & 177.4 \\
\hline Median/Mediana & 2.3 & 1.1 & 1.1 & 38.6 & 66.9 & 64.7 \\
\hline $\begin{array}{r}\text { Standard deviation/ } \\
\text { Odchylenie standardowe }\end{array}$ & 6.4 & 3.0 & 2.3 & 63.8 & 199.4 & 323.1 \\
\hline
\end{tabular}

${ }^{1}$ urban commune/gmina miejska, ${ }^{2}$ rural commune/gmina wiejska

Source: authors' own study based on BDL and GUS data.

Źródło: opracowanie własne na podstawie danych BDL, GUS. 
points to their high diversification. Based on the calculations of Schneider's indicator average value, it has been demonstrated there were 53 tourists per one hundred residents. The calculations of Charvat's indicator show that on average tourists were provided 149 overnight stays per one hundred residents. It is worth noting that similar values of both indicators were obtained in the studies of Wielkopolska landscape parks (Uglis, Jęczmyk 2015). The highest values of both indicators were found in the communes of Lądek Zdrój, Walim, Stara Kamienica, Stronie Śląskie. In turn, the least tourists and overnight stays in relation to the number of inhabitants were recorded in the communes of Dobromierz, Żmigród, Miękinia and Marciszów.

An important measure used to conduct a better analysis of the intensity of tourist traffic is the tourism density indicator (Defert's tourist function) showing the number of tourists making use of accommodation per $1 \mathrm{~km}^{2}$. Undoubtedly the availability of tourist accommodation represents a significant value for both the size and the spatial diversification of the tourist traffic density. It is confirmed by the high, statistically significant, value of Pearson's correlation indicator $\left(r_{x y}=0.925, p\right.$ $<0.001)$. The analysis of the value of Defert's tourist function indicator revealed that most tourists used accommodation in the communes of Jedlina-Zdrój and Wałbrzych. It is worth noting that in three of the surveyed communes this number exceeded 500 and more than 100 tourists used accommodation in a total of 17 units.

Based on the analysis of correlation, the existence of a statistically significant linear correlation between the percentage of the surface area of the landscape park and the indicators describing the intensity of tourist traffic was not confirmed.

Unquestionably, the possibility of tourism development in a given area depends on a number of factors, in particular on the state of its tourist facilities development. The calculated values of Pearson's correlation coefficient between the indicators characterising the tourist facilities development and the intensity of tourist traffic have confirmed it.

To summarise the above analyses, it must be emphasized that the highest values for all of the analysed indicators were not found in any of the studied communes. It should therefore be concluded that the studied units are diverse in terms of fulfilling the tourist function. However, there was an attempt to isolate a homogeneous group of units regarding the level of tourist function development based on the calculated indicators. For this purpose, the agglomeration analysis according to Ward's method using a Euclidean distance was applied. The results of grouping are shown in Figure 2.

Based on the analysis of the chart representing bonds in relation to the binding stages, a binding distance equal to 2,000 was adopted as a basis for establishing the number of clusters. Three homogenous groups were isolated with the use of this method. The first group consists of two communes with a very well-formed tourist function - Jedlina- wartości wskaźnika Charvata wynika, iż przeciętnie turystom udzielono 149 noclegów w przeliczeniu na stu rezydentów. Warto podkreślić, że podobne wartości obu wskaźników otrzymano w badaniach wielkopolskich parków krajobrazowych (Uglis, Jęczmyk 2015). Najwyższe wartości obu wskaźników stwierdzono w gminach: Lądek-Zdrój, Walim, Stara Kamienica, Stronie Śląskie. Z kolei najmniej turystów oraz udzielonych noclegów w stosunku do liczby mieszkańców odnotowano w gminach: Dobromierz, Żmigród, Miękinia i Marciszów.

Ważnym miernikiem służącym do lepszego przeanalizowania intensywności ruchu turystycznego jest wskaźnik gęstości ruchu turystycznego (funkcji turystycznej Deferta) ukazujący liczbę korzystających z noclegów przypadających na $1 \mathrm{~km}^{2}$. Niewątpliwie olbrzymie znaczenie w wielkości i przestrzennym zróżnicowaniu gęstości ruchu turystycznego ma dostępność miejsc noclegowych, co potwierdza wysoka istotna statystycznie wartość wskaźnika korelacji Pearsona $\left(\mathrm{r}_{\mathrm{xy}}=0,925, \mathrm{p}<0,001\right)$. Analizując wartości wskaźnika funkcji turystycznej Deferta stwierdzono, że najwięcej turystów skorzystało z noclegów w gminach: Jedlina-Zdrój i Wałbrzych. Warto podkreślić, że w trzech z badanych gmin liczba ta przekroczyła 500, a łącznie w 17 jednostkach korzystało z noclegów ponad 100 turystów.

Biorąc z podstawę analizę korelacji nie potwierdzono istnienia statystycznie istotnej liniowej współzależności pomiędzy udziałem powierzchni obszaru parku krajobrazowego a wskaźnikami opisującymi intensywność ruchu turystycznego.

Niewątpliwie, możliwość rozwoju turystyki na danym obszarze jest uzależniona od szeregu czynników, a w szczególności od stanu jego zagospodarowania turystycznego. Obliczone wartości współczynnika korelacji liniowej Pearsona miedzy wskaźnikami opisującymi zagospodarowanie turystyczne a opisującymi intensywność ruchu turystycznego to potwierdziły.

Rekapitulując powyższe analizy, należy podkreślić, że w żadnej z badanych gmin nie stwierdzono najwyższych wartości dla wszystkich przeanalizowanych wskaźników. Warto zatem stwierdzić, że badane jednostki są zróżnicowane pod względem pełnienia funkcji turystycznej. Niemniej jednak podjęto próbę wyodrębnienia homogenicznych grup jednostek ze względu na poziom rozwoju funkcji turystycznej na podstawie obliczonych wskaźników. W tym celu zastosowano analizę aglomeracji metodą Warda z wykorzystaniem odległości euklidesowej. Wyniki grupowania przedstawia rysunek 2 .

Na podstawie analizy wykresu odległości wiązania względem etapów wiązania, jako podstawę wyodrębnienia liczby skupień, przyjęto odległość wiązania równą 2000. W ten sposób wyznaczono trzy jednorodne grupy. Pierwszą grupę tworzą dwie gminy o najlepiej wykształconej funkcji turystycznej - Jedlina-Zdrój i Wałbrzych. Kolejną grupę tworzy pięć gmin o dobrze wykształconej funkcji turystycznej: Lądek-Zdrój, Stara Kamienica, Walim, Stronie Śląskie, Bystrzyca Kłodzka. Ostatnią trzecią grupę gmin o najsłabiej rozwiniętej funkcji turystycznej tworzą pozostałe gminy - łącznie 


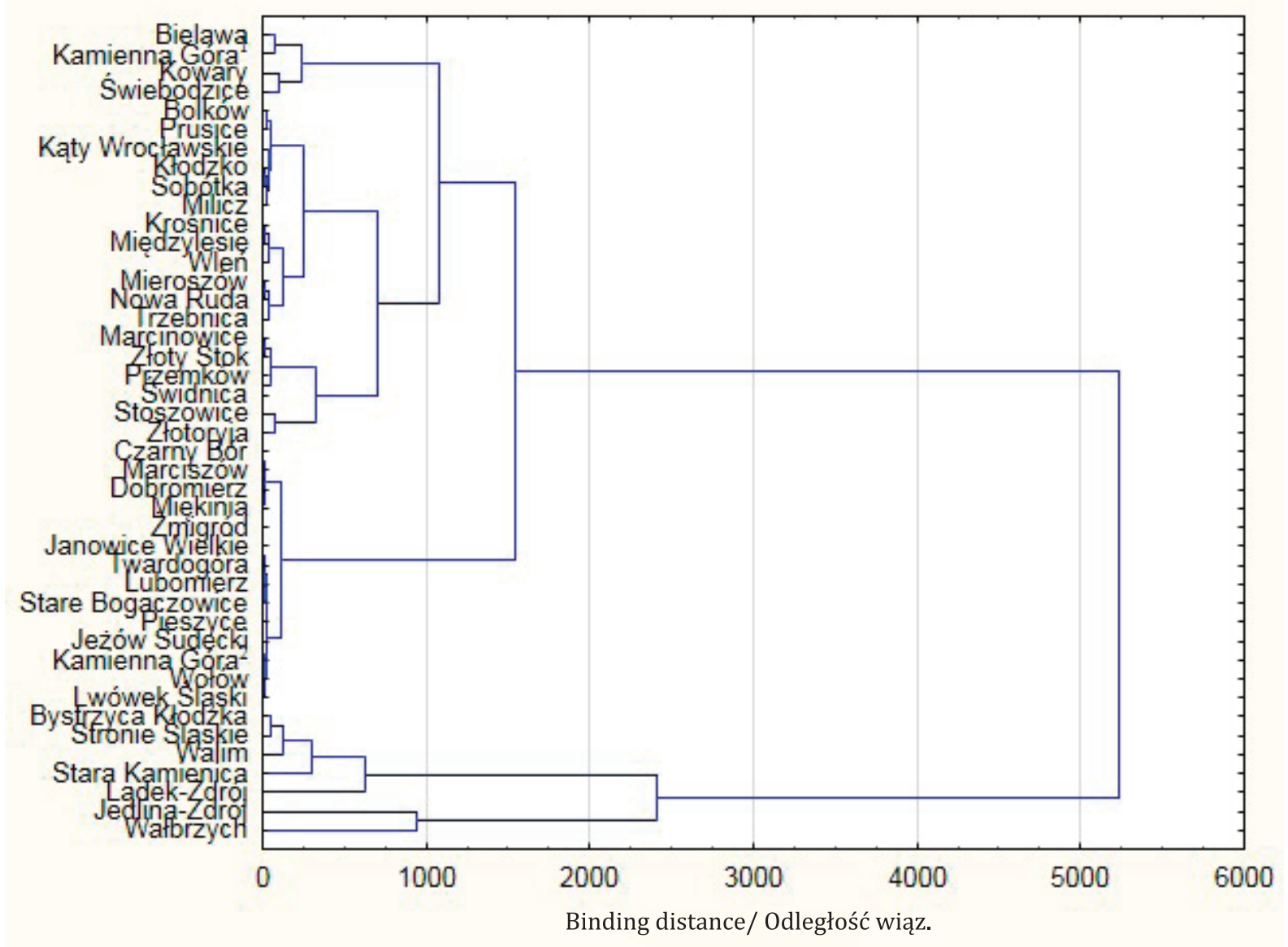

Figure 2. The results of cluster analysis using Ward's method Rysunek 2. Wyniki analizy skupień metodą Warda

Source: author's own elaboration.

Źródło: opracowanie własne.

Zdrój and Wałbrzych. Another group consists of five communes with a well-formed tourist function: Lą dek Zdrój, Stara Kamienica, Walim, Stronie Śląskie, Bystrzyca Kłodzka. The last, third, group of communes with a poorly developed tourist function consists of the remaining communes - 36 altogether. In order to evaluate the homogeneity of the obtained clusters using Ward's method, the k-means method was applied. As a result of the analysis, identical groups were found when grouping into three clusters.

At this point it is worth noting that based on the available statistical data one more group of fourteen communes was extracted (Boguszów-Gorce, Cieszków, Dzierżoniów, Gaworzyce, Gromadka, Jordanów Śląski, Łagiewniki, Gmina Męcinka, Mietków, Mysłakowice, Paszowice, Radwanice, Sobótka, Wińsko, Złotoryja). The tourist function in these areas was not formed - according to the data collected by GUS, no tourist accommodation facility was available on their territory in 2014.

\section{Conclusions}

Lower Silesian landscape parks are the perfect tourist destination for domestic and foreign tourists. These parks are characterised by considerable
36. W celu oceny homogeniczności otrzymanych skupień metodą Warda posłużono się metodą k-średnich. W wyniku analizy ustalono identyczne grupy przy grupowaniu na trzy skupiska.

W tym miejscu warto podkreślić, że na podstawie dostępnych danych statystycznych wyodrębniono jeszcze jedną grupę czternastu gmin (Boguszów-Gorce, Cieszków, Dzierżoniów, Gaworzyce, Gromadka, Jordanów Śląski, Łagiewniki, Męcinka, Mietków, Mysłakowice, Paszowice, Radwanice, Sobótka, Wińsko, Złotoryja), na terenie których funkcja turystyczna nie została wykształcona, gdyż według danych GUS na ich terenie w 2014 r. nie funkcjonował ani jeden turystyczny obiekt noclegowy.

\section{Wnioski}

Dolnośląskie parki krajobrazowe stanowią doskonały cel wyjazdów turystycznych dla turystów krajowych i zagranicznych. Parki te charakteryzują się 
diversity of nature and landscape, allowing for the pursuit of various forms of tourism and recreation ${ }^{3}$.

The development of the tourist function in landscape parks is determined by many factors, and the primary conditions are the local natural, cultural and landscape attractions. However, in order to become an object of tourist peregrination, they require appropriate tourism development. The conducted studies demonstrated significant variation in the development of tourist facilities and consequently the intensity of tourist traffic. In total, within the administrative boundaries of the studied communes, in which the Lower Silesian landscape parks are located, 177 tourist accommodation facilities were in operation, offering over 8 thousand bed places. On average, there was 4.9 facility for 100 $\mathrm{km}^{2}$, with a median equal to 2.3. In the process of conducting the study it emerged that there were no tourist accommodation facilities in 14 out of 59 surveyed communes. The analysis of correlation confirmed the existence of a statistically significant correlation between the share of the landscape park area and the calculated indicators of the development level

Indicators describing tourist traffic in the studied units were also characterised by high spatial diversification. By means of comparison of the calculated indicators, it was noted that health resorts dominate (Jedlina-Zdrój, Lądek Zdrój) in terms of traffic density (Defert's indicator).

The analysis of agglomeration using Ward's method resulted in isolating three homogeneous collections of communes with regard to the level of tourist facilities development: group 1 - communes with a very well-formed function (2), group 2 communes with a well-formed function 95) and group 3 - units with a poorly developed function (36).

Summing up the result of the study, it is clear that the highest level of tourist facilities development was established in the communes associated with Śnieżnicki Landscape Park, Sudety Wałbrzyskie Mountains Landscape Park, Owl Mountains Landscape Park, Książ Landscape Park and Bóbr River Valley Landscape Park. znaczną różnorodnością przyrodniczą i krajobrazową, co sprawia że na ich terenie można uprawiać wielorakie formy turystyki i rekreacji ${ }^{3}$.

Rozwój funkcji turystycznej parków krajobrazowych jest determinowana wieloma czynnikami, a podstawowymi $\mathrm{z}$ nich są lokalne walory przyrodnicze, kulturowe i krajobrazowe. Jednakże, aby stały się one obiektem peregrynacji turystów, wymagają odpowiedniego zagospodarowania turystycznego. $\mathrm{Na}$ podstawie przeprowadzonych badań wykazano znaczne zróżnicowanie rozwoju zagospodarowania turystycznego i w konsekwencji intensywności ruchu turystycznego. Łącznie $\mathrm{w}$ granicach administracyjnych badanych gmin, na terenie których zlokalizowane są dolnośląskie parki krajobrazowe, działalność prowadziło 177 turystycznych obiektów noclegowych oferujących ponad 8 tys. miejsc noclegowych. Przeciętnie na $100 \mathrm{~km}^{2}$ przypadało 4,9 obiektu, przy medianie równej 2,3. W trakcie badania okazało się również, że w 14 z 59 badanych gmin nie stwierdzono ani jednego turystycznego obiektu noclegowego. Poprzez analizę korelacji potwierdzono istnienie statystycznie istotnej współzależności między udziałem powierzchni parku krajobrazowego a obliczonymi wskaźnikami poziomu zagospodarowania

Dużym zróżnicowaniem przestrzennym charakteryzowały się również wskaźniki opisujące ruch turystyczny w badanych jednostkach. Porównując obliczone wskaźniki zauważa się, że pod względem gęstości ruchu (wskaźnik Deferta) dominują gminy uzdrowiskowe (Jedlina-Zdrój, Lądek-Zdrój).

W wyniku przeprowadzonej analizy aglomeracji metodą Warda wyznaczono trzy homogeniczne zbiory gmin określające poziom rozwoju funkcji turystycznej: grupa 1 - gminy o bardzo dobrze wykształconej funkcji (2), grupa 2 - gminy o dobrze wykształconej funkcji 95) oraz grupa 3 - jednostki o słabo rozwiniętej funkcji (36).

Podsumowując wynik przeprowadzonych badań, należy stwierdzić, że najwyższy poziom rozwoju funkcji turystycznej określono w gminach związanych z Śnieżnickim PK, PK Sudetów Wałbrzyskich, PK Gór Sowich, Księżańskim PK i PK Doliny Bobru.

\section{References/Literatura:}

1. Derek M. (2007), Gmina turystyczna - ujęcie metodologiczno-metodyczne, W: W. Kurek, R. Pawlusiński (red.), Studia nad turystyka. Prace ekonomiczne i społeczne. Geograficzne, społeczne i ekonomiczne aspekty turystyki. Wydawnictwo Instytutu Geografii i Gospodarki Przestrzennej, Uniwersytet Jagielloński, Kraków, s. 27-32.

2. Derek M. (2008), Funkcja turystyczna jako czynnik rozwoju lokalnego w Polsce. Uniwersytet Warszawski, Warszawa, manuskrypt pracy doktorskiej.

3. Dziedzic E. (2003), Rachunek satelitarny jako narzędzie mierzenia efektów ekonomicznych turystyki, W: G. Gołembski (red.), Kierunki rozwoju badań naukowych w turystyce. Akademia Ekonomiczna w Poznaniu, Poznań, s. 43-52.

4. Gałecki R. (2004), Znaczenie efektu mnożnikowego wpływów z turystyki dla rozwoju regionu i miejscowości, W: R. Gałecki (red.), Rola i zadania samorządu terytorialnego w rozwoju gospodarki turystycznej. Mazowiecka Wyższa Szkoła Humanistyczno-Pedagogiczna w Łowiczu, Łowicz, s. 113-117.

5. Graja-Zwolińska S., Spychała A. (2014), Turystyka na obszarach parków krajobrazowych. Studium przypadku Zespołu Wielkopolskich Parków Krajobrazowych, W: S.J. Snarski, M. Jalinik (red.), Przedsiębiorczość w turystyce, EkoPress, Białystok, s. 291-305.

${ }^{3}$ A set of dominant forms of tourism in Lower Silesian landscape parks was presented by Mastalska-Cetera and Warczewska (2015, pp. 39-40) ${ }^{3}$ Zestaw dominujących form turystyki w dolnośląskich parkach
krajobrazowych przedstawiła Mastalska-Cetera i Warczewska $(2015$, s. 39-40). 
6. Hendel M. (2016), Przydatność wskaźników funkcji turystycznej w ocenie rozwoju turystycznego obszaru na przykładzie gminy Ustroń. Zeszyty Naukowe Politechniki Śląskiej, Seria: Organizacja i Zarządzanie z. 87, Nr kol. 1947, s. 157-170.

7. Hibszer A. (2012), Korzyści z sq̨siedztwa parku narodowego w opinii lokalnych społeczności. Acta Geographica Silesiana, nr 12, s. 13-25.

8. Jackowski A. (1981), Typologia funkcjonalna miejscowości turystycznych (na przykładzie województwa nowosądeckiego). Uniwersytet Jagielloński, Kraków.

9. Kachniewska M. (2011), Funkcja turystyczna jako determinanta jakości życia na wsi. Folia Pomer. Univ. Technol. Stetin. Oeconomica, nr 288 (64), s. 53-72.

10. Kobyłka A., Sawicki B. (2016), Uwarunkowania rozwoju agroturystyki na obszarach parków krajobrazowych województwa lubelskiego. Ekonomia i Środowisko, nr 1 (56), s. 208-222.

11. Kowalska M., Knapik W., Bogusz M., Kiełbasa B., Niedziółka A., Piotrowska A., Satoła Ł. (2015), Rozwój lokalny obszarów wiejskich w perspektywie społeczno-ekonomicznej. Wyd. Uniwersytet Rolniczy w Krakowie.

12. Kurek W. (red.) (2007), Turystyka. Wydawnictwo Naukowe PWN, Warszawa.

13. Łazarek, R. (2004), Ekonomika turystyki, Wybrane zagadnienia. Wyższa Szkoła Ekonomiczna, Warszawa.

14. Mastalska-Cetera B., Warczewska B. (2015), Możliwości rozwoju turystyki zrównoważonej na przykładzie dolnośląskich parków krajobrazowych. Prace naukowe Uniwersytetu Ekonomicznego we Wrocławiu, nr 379, Wrocław, s. 32-44.

15. Matczak A. (1989), Problemy badania funkcji turystycznej miast Polski, W: Funkcja turystyczna. Acta Univesitatis Lodziensis - Turyzm, 5, s. 27-39.

16. Ochrona środowiska (2015). Główny Urząd Statystyczny, Warszawa, 2015.

17. Piotrowski P. (2015), Zmiany poziomu rozwoju funkcji turystycznej w rejonach turystycznych województwa ślq̨skiego. Studia Ekonomiczne. Zeszyty Naukowe Uniwersytetu Ekonomicznego w Katowicach, nr 2015, s. 57-73.

18. Radziejowski J. (2006), Jak tworzenie terenów chronionych sprzyja lokalnemu rozwojowi? Centrum Badań nad Środowiskiem Przyrodniczym UW.

19. Radziejowski J. (2011), Obszary chronionej przyrody. Historia, stan obecny, wyzwania przyszłości. Wszechnica Polska Szkoła Wyższa TWP w Warszawie.

20. Sokołowski D., Szyda B., Mierkiewicz W. (2011), Funkcja turystyczna Zaborskiego Parku Krajobrazowego. Studia i Materiały CEPL w Rogowie, r. 13, z. 3 (28), s. 245-250.

21. Spychała A. (2010), Funkcja turystyczna Parku Krajobrazowego „Dolina Baryczy”. Bogucki Wydawnictwo Naukowe, Poznań.

22. Szromek A. R. (2013a), Pomiar funkcji turystycznej obszarów za pomoca wskaźników funkcji turystycznej na przykładzie obszarów państw europejskich, W: Zastosowania metod matematycznych w ekonomii i zarzqdzaniu. Studia Ekonomiczne, Uniwersytet Ekonomiczny w Katowicach, nr 132, s. 91-103.

23. Szromek A. R. (2013b), Wskaźniki funkcji turystycznej i ich współzależność z innymi wskaźnikami ekonomicznymi na przykładzie polskiej gospodarki w latach 2000-2010. Prace Naukowe Uniwersytetu Ekonomicznego we Wrocławiu nr 304, Wrocław, s. 336-349.

24. Uglis J., Jęczmyk A. (2015), Rozwój funkcji turystycznej obszarów wielkopolskich parków krajobrazowych. Ekonomia i Środowisko, nr 4 (55), s. 153-164.

25. Zajadacz A. (2014), Dostępność przestrzeni turystycznej w ujęciu geograficznym. Turyzm, nr 1 (24), s. 49-57.

\section{Websites/ Strony internetowe:}

26. http://dzpk.pl/

27. https://www.mos.gov.pl/ 